Gut, 1964, 5, 188

\title{
Steatorrhoea and diarrhoea after vagotomy: a comparison of drainage procedures
}

\author{
HUME LOGAN ${ }^{1}$ \\ From the Royal Infirmary, Leicester
}

EDITORIAL SYNOPSIS From this study it is concluded that steatorrhoea and diarrhoea are due to the vagotomy and not to the drainage procedure.

Steatorrhoea and diarrhoea follow all types of gastric surgery but their incidence is probably highest when vagotomy is performed. This investigation was undertaken in an attempt to answer the following questions: What is the incidence of diarrhoea and steatorrhoea after vagotomy accompanied by either pyloroplasty or gastrojejunostomy? Is there a significant difference in the incidence of steatorrhoea and diarrhoea with these two types of drainage procedure? What effect does steatorrhoea, or diarrhoea, or both, have on the patient's body weight?

\section{MATERIAL AND METHODS}

All the patients were male and had been operated on between one and two years before the time of investigation. These patients were called for interview and 66 complied. They were questioned regarding the result of their operation and their bowel habits before and after surgery. They were asked to collect their stools for three consecutive days. The number of patients in each group, their age, time from operation, and the number of satisfactory specimens received are summarized in Table $I$.

TABLE I

NUMBER OF PATIENTS INTERVIEWED AND AGES, TIMES SINCE OPERATION, AND NUMBER OF SPECIMENS

Vagotomy and Vagotomy and Pyloroplasty Gastro-

jejunostomy

Number of patients

Age

Months since operation (mean)

Satisfactory specimens
35

23-63 (47.3)

$12-20(14 \cdot 2)$

28
27-80 (48.5)

$12-21(16.9)$

21

RESULTS

INCIDENCE OF POST-VAGOTOMY DIARRHOEA Twentysix $(39.4 \%)$ of the 66 patients noticed some change in bowel habit following operation. As this varied from having more regular defaecation to pronounced diarrhoea, it is necessary to classify the changes encountered. The following four categories came nearest to grading the severity of the changes noted. I Troublesome diarrhoea; II fluid or loose stools without any change in frequency or marked increase in frequency, but no fluid stools; III occasional loose stool or more regular defaecation; and IV no change in bowel habit.

Table II shows the number of patients in each category and for both types of operation. The

\section{TABLE II}

BOWEL SYMPTOMS AFTER VAGOTOMY AND DRAINAGE PROCEDURES ${ }^{1}$

Bowel Vagotomy and Vagotomy and Total Percentage

Category Gastro- $\quad$ Pyloroplasty $\quad$ of Total

jejunostomy

\begin{tabular}{lrrrr}
\hline I & 1 & 2 & 3 & $4 \cdot 5$ \\
II & 2 & 4 & 6 & $9 \cdot 1$ \\
III & 10 & 7 & 17 & $25 \cdot 8$ \\
IV & 18 & 22 & 40 & $60 \cdot 6$ \\
Total & 31 & 35 & 66 & \\
IF & & &
\end{tabular}

incidence of frank diarrhoea $(4.5 \%)$ is very similar to that given by Feggetter (1959) but much less than that given by the other authors in Table III. If the patients in category II are added, the incidence of diarrhoea rises to $13.6 \%$ which is similar to the figure of $12.0 \%$ given by Burge, Rizk, Tompkin, Barth, Hutchison, Longland, McLennan, and Miln (1961) for selective vagotomy.

As all the patients had a normal appetite it and $150 \mathrm{~g}$. and that the normal faecal fat level shoul by the method based on that described by Van de Kamer (1958) and recommended by Frazer (1960).

${ }^{1}$ Present address: Royal Victoria Hospital, Belfast. 
TABLE III

INCIDENCE OF DIARRHOEA AFTER VAGOTOMY AND PYLOROPLASTY OR GASTROJEJUNOSTOMY AS CITED BY DIFFERENT AUTHORS

\begin{tabular}{|c|c|c|c|}
\hline Author & Operation & $\begin{array}{l}\text { No. of } \\
\text { Cases }\end{array}$ & $\begin{array}{l}\text { Incidence of } \\
\text { Post-vagotomy } \\
\text { Diarrhoea }(\%)\end{array}$ \\
\hline Davies (1956) & $\begin{array}{l}\text { Pyloroplasty } \\
\text { Gastrojejunostomy }\end{array}$ & 330 & $22 \cdot 5$ \\
\hline Burge and Pick (1958) & Gastrojejunostomy & 282 & $30 \cdot 0$ \\
\hline Clark (1961) & Gastrojejunostomy & 67 & $22 \cdot 0$ \\
\hline Burge et al. (1961) & Selective vagotomy & 100 & $12 \cdot 0$ \\
\hline Feggetter (1959) & $\begin{array}{l}\text { Unselective } \\
\text { vagotomy and } \\
\text { gastrojejunostomy }\end{array}$ & 661 & $4 \cdot 2$ \\
\hline Present series & $\begin{array}{l}\text { Unselective } \\
\text { vagotomy } \\
\text { Pyloroplasty } \\
\text { Gastrojejunostomy }\end{array}$ & 66 & $13 \cdot 6$ \\
\hline
\end{tabular}

INCIDENCE OF STEATORRHOEA Ten $(37.6 \%)$ of the 28 patients with pyloroplasty and six $(28.6 \%)$ of the 21 patients with gastrojejunostomy had faecal fat values greater than $5 \mathrm{~g}$.

RELATIONSHIP OF DIARRHOEA TO BODY WEIGHT Only one of the 16 patients with an average faecal fat level above $5 \mathrm{~g}$. per day (Table V) had lost weight since operation and eight patients had increased their weight.

\section{DISCUSSION}

In elucidating the cause of post-vagotomy diarrhoea it is necessary to understand the alterations in gastrointestinal physiology produced by vagotomy.

GASTRIC AND INTESTINAL MOBILITY The gastric stasis caused by vagotomy makes a drainage procedure obligatory. The latter, however, may cause rapid gastric emptying. Kay (1962) has shown that the average period of intestinal paralysis after vagotomy is 14 hours, and remarks that small bowel mobility is almost entirely dependent on intrinsic nerve mechanisms and virtually independent of extrinsic nerve influence. Guyton (1961) states that vagotomy decreases peristalsis but that after a period of months this is compensated for by increased excitability of the intrinsic nervous system. Following vagotomy and gastrojejunostomy Burge and Clark (1959) did not demonstrate intestinal hurry by radiological means. It would seem improbable, therefore, that changes in gastric and intestinal mobility play any part in the production of postvagotomy diarrhoea or steatorrhoea.

BILIARY AND PANCREATIC SECRETIONS Vagotomy would be expected to lower the volume of the external secretion of the pancreas as the vagus is secretomotor to this gland. Routley, Mann, Bollman, and Grindlay (1952) showed that vagotomy caused no significant change in the external pancreatic secretion in dogs. Experience with partial pancreatectomy has shown that large amounts of the pancreas can be removed without the production of steatorrhoea or diarrhoea. However, Vanamee (1960) showed that hypertonic solutions entering the jejunum may decrease external pancreatic secretion in dogs and this might result from the drainage procedure. Also, vagotomy, by lowering the $p \mathrm{H}$ of the gastric efflux, may make it an ineffective stimulus for the liberation of secretin.

Johnson and Boyden (1952) found that dilatation of the gall bladder occurs after vagotomy but that emptying is under hormonal control and the rate of emptying is not appreciably altered after ingestion of a fatty meal. Thus, it would appear that vagotomy does not radically alter the liberation of bile. Nevertheless, Polak and Pontes (1956) showed that ox bile extract reduced the steatorrhoea to normal levels in five patients with total gastrectomy and four patients with subtotal gastrectomy, while pancreatin had no effect. Further investigation of biliary and hepatic function after vagotomy seems warranted.

GASTRIC AND INTESTINAL SECRETION Vagotomy reduces gastric secretion by $65 \%$ in the vast majority of patients (Kay, 1962). Dragstedt (1962) postulates that hypochlorhydria and stasis in the atonic stomach lead to the growth of bacteria in the stomach and intestine. Goldstein, Wirts, and Kramer (1961) cultured bacterial flora approaching that of the colon from the duodenojejunal loop of gastrectomized patients with steatorrhoea. Stasis, however, has not generally been demonstrated in patients with pyloroplasties or gastrojejunostomies.

In view of the large quantities of succus entericus secreted, it is probable that vagotomy has little effect on intestinal secretion since local factors seem to be more important in its control.

Thus, no one cause can be credited with the production of post-vagotomy diarrhoea and steatorrhoea. However, the studies undertaken help to elucidate some of the problems.

It has already been observed that $39.4 \%$ of the patients noted some change in bowel habit. Of these, $13.6 \%$ are in categories I and II and these are considered to have post-vagotomy diarrhoea. Their symptoms and faecal fat levels are described in Table IV. It can be seen that only four of the nine patients having diarrhoea had an average daily faecal fat level above $5 \mathrm{~g}$. Thus, the diarrhoea resulting from vagotomy does not cause steatorrhoea. 
TABLE IV

SYMPTOMS OF PATIENTS CONSIDERED TO HAVE POST-VAGOTOMY DIARRHOEA, WITH TYPE OF DRAINAGE PROCEDURE, AVERAGE DAILY FAECAL FAT LEVEL, AND NUTRITIONAL STATE SINCE OPERATION

\begin{tabular}{|c|c|c|c|c|c|}
\hline Patient Number & Bowel Symptoms & $\begin{array}{l}\text { Bowel } \\
\text { Category }\end{array}$ & Drainage Procedure & $\begin{array}{l}\text { Average Daily } \\
\text { Faecal Fat } \\
(\text { g./day) }\end{array}$ & $\begin{array}{l}\text { Change in } \\
\text { Weight since } \\
\text { Operation (lb.) }\end{array}$ \\
\hline P10 & $\begin{array}{l}\text { Diarrhoea once or twice a week; none } \\
\text { pre-operatively }\end{array}$ & I & Pyloroplasty & $2 \cdot 2$ & +28 \\
\hline P14 & $\begin{array}{l}\text { Periodic malodorous diarrhoea once every } \\
3 \text { weeks; lasts } 1 \text { night with approximately } \\
8 \text { movements }\end{array}$ & I & Pyloroplasty & $5 \cdot 8$ & Nil \\
\hline P12 & $\begin{array}{l}\text { Pre-operatively defaecated once every } 2 \text { days; } \\
\text { now } 2 \text { movements a day; soft but no diarrhoea }\end{array}$ & II & Pyloroplasty & $7 \cdot 2$ & Nil \\
\hline P16 & $\begin{array}{l}\text { One movement a day pre-operatively; now } 2 \\
\text { movements a day; loose but no diarrhoea }\end{array}$ & II & Pyloroplasty & $3 \cdot 5$ & +7 \\
\hline P21 & Stools more fluid; very soft; once a day & II & Pyloroplasty & 1.4 & +28 \\
\hline P27 & $\begin{array}{l}\text { Constipation pre-operatively; one movement } \\
\text { every } 2 \text { days; now twice a day; sometimes loose }\end{array}$ & II & Pyloroplasty & $1 \cdot 8$ & +14 \\
\hline G20 & $\begin{array}{l}\text { Constant diarrhoea } 3 \text { to } 4 \text { days each week; } \\
3 \text { to } 4 \text { movements a day; improving }\end{array}$ & I & Gastrojejunostomy & $2 \cdot 2$ & -7 \\
\hline G10 & $\begin{array}{l}\text { One movement a day pre-operatively; now } 4 \text { times } \\
\text { a day; loose but not diarrhoea }\end{array}$ & II & Gastrojejunostomy & $7 \cdot 8$ & Nil \\
\hline G13 & $\begin{array}{l}\text { One movement a day pre-operatively; now twice } \\
\text { a day; had diarrhoea, but now gone }\end{array}$ & II & Gastrojejunostomy & $8 \cdot 5$ & +14 \\
\hline
\end{tabular}

TABLE V

BOWEL CATEGORY AND WEIGHT CHANGE SINCE OPERATION IN PATIENTS WITH STEATORRHOEA

\begin{tabular}{|c|c|c|c|c|}
\hline Patient Number & Operation & Faecal Fat (g./day) & Bowel Category & $\begin{array}{l}\text { Change in Weight Since } \\
\text { Operation (lb.) }\end{array}$ \\
\hline $\begin{array}{l}\text { P3 } \\
\text { P12 } \\
\text { P13 } \\
\text { P14 } \\
\text { P17 } \\
\text { P22 } \\
\text { P23 } \\
\text { P24 } \\
\text { P25 } \\
\text { P28 } \\
\text { G7 } \\
\text { G9 } \\
\text { G10 } \\
\text { G13 } \\
\text { G16 } \\
\text { G18 }\end{array}$ & $\begin{array}{l}\text { Pyloroplasty } \\
\text { Pyloroplasty } \\
\text { Pyloroplasty } \\
\text { Pyroloplasty } \\
\text { Pyloroplasty } \\
\text { Pyloroplasty } \\
\text { Pyloroplasty } \\
\text { Pyloroplasty } \\
\text { Pyloroplasty } \\
\text { Pyloroplasty } \\
\text { Gastrojejunostomy } \\
\text { Gastrojejunostomy } \\
\text { Gastrojejunostomy } \\
\text { Gastrojejunostomy } \\
\text { Gastrojejunostomy } \\
\text { Gastrojejunostomy }\end{array}$ & $\begin{array}{l}7 \cdot 4 \\
7 \cdot 2 \\
6 \cdot 0 \\
5 \cdot 8 \\
7 \cdot 7 \\
5 \cdot 6 \\
6 \cdot 0 \\
7 \cdot 6 \\
5 \cdot 5 \\
5 \cdot 5 \\
5 \cdot 8 \\
6 \cdot 7 \\
7 \cdot 8 \\
8 \cdot 5 \\
8 \cdot 2 \\
5 \cdot 9\end{array}$ & $\begin{array}{l}\text { IV } \\
\text { II } \\
\text { IV } \\
\text { I } \\
\text { IV } \\
\text { III } \\
\text { IV } \\
\text { IV } \\
\text { III } \\
\text { IV } \\
\text { IV } \\
\text { IV } \\
\text { II } \\
\text { II } \\
\text { III } \\
\text { III }\end{array}$ & $\begin{array}{l}\text { Nil } \\
\text { Nil } \\
\text { Slight increase } \\
\text { Nil } \\
\text { Slight increase } \\
\text { Nil } \\
\text { Nil } \\
\text { Slight decrease } \\
+7 \\
\text { Nil } \\
+28 \\
+14 \\
\text { Nil } \\
+14 \\
\text { Slight increase } \\
+24\end{array}$ \\
\hline
\end{tabular}

Three patients $(9 \cdot 7 \%)$ who had gastrojejunostomy and six $(17 \cdot 1 \%)$ who had pyloroplasty are considered to have post-vagotomy diarrhoea. The higher incidence of diarrhoea with pyloroplasty excludes short circuiting of the duodenal loop as the cause of diarrhoea.

Ten $(37.6 \%)$ of the 28 patients with pyloroplasty and six $(28.6 \%)$ of the 21 patients with gastrojejunostomy had faecal fat levels greater than $5 \mathrm{~g}$. per day. These figures are not significantly different $\left(p=0.86 ; \chi^{2}\right.$ corrected for small numbers of observations). This suggests that steatorrhoea is the result of the vagotomy and not the type of drainage procedure employed.

From Table $\mathrm{V}$ it can be seen that of the 16 patients with steatorrhoea four are in categories I and II while 12 are in categories III and IV. This confirms the belief that post-vagotomy steatorrhoea is not the cause of post-vagotomy diarrhoea. Although the terms post-vagotomy diarrhoea and post-vagotomy steatorrhoea are often used synonymously, this is not so.

Changes in body weight do not necessarily indicate the state of body nutrition but it is interesting to compare any alteration brought about by steatorrhoea or diarrhoea. The one patient (G20) who lost weight had severe post-vagotomy diarrhoea and it would appear that only under these circumstances is weight loss encountered. None of the patients with post-vagotomy steatorrhoea had any appreciable weight loss, and this, therefore, does not lead to malnutrition.

\section{SUMMARY AND CONCLUSIONS}

Sixty-six patients who had had a vagotomy and drainage procedure more than one year before interview were questioned regarding their bowel 
habit. Faecal fat levels were obtained in 49 of these. Following vagotomy, diarrhoea and steatorrhoea occur independently of each other.

Steatorrhoea and diarrhoea are probably caused by vagotomy and not by the drainage procedure. Mixing of food and juices in the duodenal loop does not lower the incidence of either diarrhoea or steatorrhoea.

Only diarrhoea of the most severe type following vagotomy affects body weight while steatorrhoea has no effect. No single cause can be blamed for either the steatorrhoea or diarrhoea which follows vagotomy.

Without the cooperation of the surgeons of the Leicester Royal Infirmary and the Leicester General Hospital this study would not have been possible. I wish to thank them and Dr. Victor Pugh, of the Pathological Laboratory, Leicester Royal Infirmary, for his advice and for undertaking the faecal fat estimations. I am also grateful to Professor A. W. Kay, University of Sheffield, for his help and encouragement.

\section{REFERENCES}

Burge, H., and Clark, P. A. (1959). Post-vagotomy diarrhoea: its cause and prevention. Brit. med. J., 1, 1142-1144.

gastro-enterostomy in chronic duodenal ulceration: a comparison with gastrectomy. Ibid., 1, 613-615.
Burge, H. W., Rizk, A. R., Tompkin, A. M. B., Barth, C. E., Hutchison, J. S. F., Longland, C. J., McLennan, I., and Miln, D. C. (1961). Selective vagotomy in the prevention of postvagotomy diarrhoea. Lancet, 2, 897-899.

Clark, C. G. (1961). Vagotomy for peptic ulcer. Brit. med. J., 1 , 1250-1251.

Davies, J. A. L. (1956). Late results of vagotomy combined with gastro-jejunostomy or pyloroplasty in the treatment of duodenal ulceration. Ibid., 2, 1086-1091.

Dragstedt, R. L. (1962). Section of the vagus nerves to the stomach in the treatment of duodenal ulcer. In Surgery of the Stomach and Duodenum, edited by $\mathrm{H}$. N. Harkins and L. M. Nyhus, pp. 461-469. Little, Brown, Boston.

Feggetter, G. Y. (1959). Treatment of chronic duodenal ulcer by vagotomy and posterior gastroenterostomy. Proc. roy. Soc. Med., 52, 838-839.

Frazer, A. C. (1960). Daily Fatty Acid Excretion. Broadsheet No. 28, Association of Clinical Pathologists.

Goldstein, F., Wirts, C. W., and Kramer, S. (1961). The relationship of afferent limb stasis and bacterial flora to the production of postgastrectomy steatorrhea. Gastroenterology, 40, 47-55.

Guyton, A. C. (1961). Textbook of Medical Physiology. Saunders, Philadelphia and London.

Johnson, F. E., and Boyden, E. A. (1952). The effect of double vagotomy on the motor activity of the human gall bladder. Surgery, 32, 591-601.

Kay, A. W. (1962). Gastro-intestinal surgery and human physiology. J. roy. Coll. Surg. Edinb., 7, 275-288.

Polak, M., and Pontes, J. F. (1956). The cause of postgastrectomy steatorrhea. Gastroenterology, 30, 489-499.

Routley, E. F., Mann, F. C., Bollman, J. L., and Grindlay, J. H. (1952). Effects of vagotomy on pancreatic secretion in dogs with chronic pancreatic fistula. Surg. Gynec. Obstet., 95, 529-536.

Vanamee, P. (1960). Nutrition after gastric resection. J. Amer. med. Ass., 172, 2072-2076.

Van de Kamer, J. H. (1958). In American Association of Clinical Chemists. Standard Methods in Clinical Chemistry, vol. 2, p. 34. Academic Press, New York. 